\title{
An Alternative Approach for the Management of Bone Health: Role of Biofield Energy Healing Treated Vitamin $D_{3}$
}

\author{
Brian Anthony Weekes ${ }^{1}$, Mahendra Kumar Trivedi ${ }^{1}$, Alice Branton ${ }^{1}$, Dahryn Trivedi ${ }^{1}$, \\ Gopal Nayak ${ }^{1}$, Sambhu Charan Mondal', Snehasis Jana ${ }^{2, *}$ \\ ${ }^{1}$ Trivedi Global, Inc., Henderson, USA \\ ${ }^{2}$ Trivedi Science Research Laboratory Pvt. Ltd., Bhopal, India
}

Email address:

publication@trivedisrl.com (S. Jana)

${ }^{*}$ Corresponding author

\section{To cite this article:}

Brian Anthony Weekes, Mahendra Kumar Trivedi, Alice Branton, Dahryn Trivedi, Gopal Nayak, Sambhu Charan Mondal, Snehasis Jana. An Alternative Approach for the Management of Bone Health: Role of Biofield Energy Healing Treated Vitamin $\mathrm{D}_{3}$. American Journal of Internal Medicine. Vol. 6, No. 1, 2018, pp. 1-9. doi: 10.11648/j.ajim.20180601.11

Received: December 4, 2017; Accepted: December 13, 2017; Published: January 10, 2018

\begin{abstract}
The main aim of this experiment was to assess the impact of Consciousness Energy Healing-based vitamin $\mathrm{D}_{3}$ and DMEM medium on bone health parameters. The test items, were divided into two parts. One part of each sample received the Consciousness Energy Healing Treatment by Brian Anthony Weekes and those samples were labeled as the Biofield Energy Treated (BT) samples, while the other parts of each sample were denoted as the untreated test items (UT). Different parameters like ALP, collagen, and bone mineralization were performed to evaluate the bone strength and integrity in human bone osteosarcoma cells (MG-63). The test samples were found as safe in the tested concentrations by MTT cell viability assay. ALP was significantly increased by $19.49 \%$ and $63.49 \%$ in the UT-DMEM + BT-Test item and BT-DMEM + BT-Test item groups, respectively at $1 \mu \mathrm{g} / \mathrm{mL}$ compared to the UT-DMEM + UT-Test item group. Further, the ALP level was significantly elevated by $35.92 \%$ and $61.17 \%$ in the UT-DMEM + BT-Test item and BT-DMEM + BT-Test item groups, respectively at 10 $\mu \mathrm{g} / \mathrm{mL}$ compared to the UT-DMEM + UT-Test item group. Collagen was significantly increased by $53.75 \%$ and $42.43 \%$ in the UT-DMEM + BT-Test item and BT-DMEM + UT-Test item groups, respectively at $1 \mu \mathrm{g} / \mathrm{mL}$ compared to the untreated group. Further, the collagen level was significantly increased by $46.54 \%$ and $122.61 \%$ at 50 and $100 \mu \mathrm{g} / \mathrm{mL}$, respectively in the BTDMEM + UT-Test item group compared to the untreated group. Additionally, the percent of bone mineralization was distinctly increased by $18.12 \%, 96.33 \%$, and $150.85 \%$ in the UT-DMEM + BT-Test item, BT-DMEM + UT-Test item, and BT-DMEM + BT-Test item groups, respectively at $10 \mu \mathrm{g} / \mathrm{mL}$ compared to the untreated group. Further, the percentage of bone mineralization was significantly increased by 61.96 and $22.84 \%$ in the BT-DMEM + UT-Test item and BT-DMEM + BT-Test item groups, respectively at $100 \mu \mathrm{g} / \mathrm{mL}$ compared to the untreated group. Overall, the Biofield Energy Treated vitamin $\mathrm{D}_{3}$ was significantly improved the bone health parameters and it could be an alternative nutraceutical supplement to combat vitamin $\mathrm{D}_{3}$ deficiency and fight against various bone related problems including rickets, low bone density, osteomalacia, bone and joint pain, bone fractures, osteoporosis, osteoma, osteogenesis imperfecta, Paget's disease of bone, deformed bones, chondrodystrophia fetalis, stress management and prevention, autoimmune and inflammatory diseases, and anti-aging by improving overall health.
\end{abstract}

Keywords: Vitamin $D_{3}$ Deficiency, Biofield Energy Healing Treatment, Osteosarcoma Cells (MG-63), Bone Mineralization, Bone Health

\section{Introduction}

Vitamin D has multiple effects, which regulate the functions in different organs viz. brain, liver, lungs, heart, kidneys, skeletal, immune and reproductive systems. Moreover, it has significant anti-inflammatory, anti-aging, anti-stress, anti-arthritic, anti-osteoporosis, anti-apoptotic, wound healing, anti-cancer, anti-psychotic and anti-fibrotic 
actions [1]. Vitamin D receptors are widely distributed in most of the body organs viz. brain, liver, heart, lungs, kidney, pancreas, small and large intestines, muscles, reproductive, nervous system, etc. Vitamin D receptors influence cell-tocell communication, normal cell growth, cell differentiation, cell cycling and proliferation, hormonal balance, neurotransmission process, skin health, immune and cardiovascular functions. In any living vertebrates, vitamin D plays an important role in maintaining a healthy skeletal structure and is essential for bone health. Naturally, it is synthesized in the presence of sunlight in the skin [2]. Most foods do not contain any vitamin $\mathrm{D}$, additionally now-a-days due to aging, use of sunscreen, and change of zenith angle of sun the production of vitamin $\mathrm{D}_{3}$ has reduced [3]. Increasing age is not only related to a decrease in bone marrow depression and muscle strength but is also associated with marked changes in the immune and inflammatory responses [4]. Deficiency of vitamin $\mathrm{D}_{3}$ causes metabolic bone diseases like osteomalacia and exacerbate osteoporosis, etc. [5]. The quality of life for menopausal women is one of the most critical health problem in the today world. Metabolic bone disorders like osteoporosis are mainly prevalent in postmenopausal women. Hormonal factors and rapid bone loss in post-menopausal women leads to an increased risk of fractures [6]. Hence, the serum calcium and alkaline phosphatase (ALP) levels in post-menopausal women are the main two vital biochemical markers of bone metabolism. However, bone-specific ALP is the most important marker for osteoblast differentiation [7]. Further, it is generally accepted that an increased calcium intake along with an adequate source of vitamin D is important for maintaining good bone health. Vitamin D also plays an important role in maintaining an adequate level of serum calcium and phosphorus. Therefore, vitamin $\mathrm{D}$ has a great impact in forming and maintaining strong bones [8, 9]. Bone strength depends on the quality, geometry, shape, microarchitecture, turnover, mineral content, and the collagen content. Collagen is the major structural protein responsible for bone calcification. In the aging state, the mechanical properties of the bones become impaired and the bones get fragile, that causes various clinical disorders associated with bone collagen abnormalities and bone fragility, such as osteogenesis imperfecta and osteoporosis [10, 11].

In recent years, several scientific reports and clinical trials have revealed the useful effects of Biofield Energy Treatments, which have shown to enhance immune function in cases of cervical cancer patients via therapeutic touch [12], massage therapy [13], etc. Complementary and Alternative Medicine (CAM) therapies are now rising as preferred models of treatment, among which Biofield Therapy (or Healing Modalities) is one approach that has been reported to have several benefits to enhance physical, mental and emotional human wellness. However, as per the data of 2012 from the National Health Interview Survey (NHIS), which indicated that the highest percentage $(17.7 \%)$ of the Americans used dietary supplements as a complementary health approach as compared with other practices in past years. The National Center of Complementary and Integrative Health (NCCIH) has recognized and accepted Biofield Energy Healing as a CAM health care approach in addition to other therapies, medicines and practices such as natural products, deep breathing, yoga, Tai Chi, Qi Gong, chiropractic/osteopathic manipulation, meditation, massage, special diets, homeopathy, progressive relaxation, guided imagery, acupressure, acupuncture, relaxation techniques, hypnotherapy, healing touch, movement therapy, pilates, rolfing structural integration, mindfulness, Ayurvedic medicine, traditional Chinese herbs and medicines, naturopathy, essential oils, aromatherapy, Reiki, and cranial sacral therapy. Human Biofield Energy has subtle energy that has the capacity to work in an effective manner [14]. CAM therapies have been practiced worldwide with reported clinical benefits in different health disease profiles [15]. This energy can be harnessed and transmitted by the experts into living and non-living things via the process of Biofield Energy Healing. Biofield Energy Treatment (The Trivedi Effect ${ }^{\circledR}$ ) has been published in numerous peer-reviewed science journals with significant outcomes in many scientific fields such as cancer research [16, 17], microbiology [18-21], biotechnology [22, 23], pharmaceutical science [24-27], agricultural science [28-31], materials science [32-35], nutraceuticals [36, 37], skin health, human health and wellness.

Based on the literature information and importance of vitamin $\mathrm{D}_{3}$ on bone health, the authors sought to evaluate the impact of the Biofield Energy Treatment (The Trivedi Effect ${ }^{\circledR}$ ) on the test samples (vitamin $\mathrm{D}_{3}$ and DMEM medium) for bone health activity with respect to the assessment of different bone health parameters like ALP, collagen content, and bone mineralization using standard assays in MG-63 cells.

\section{Materials and Methods}

\subsection{Chemicals and Reagents}

Rutin hydrate was purchased from TCI, Japan, while vitamin $\mathrm{D}_{3}$ (denoted as test item) and L-ascorbic acid were obtained from Sigma-Aldrich, USA. Fetal bovine serum (FBS) and Dulbecco's Modified Eagle's Medium (DMEM) were purchased from Life Technology, USA. Antibiotic solution (penicillin-streptomycin) was procured from HiMedia, India, while 3-(4,5-dimethyl-2-thiazolyl)-2, 5diphenyl-2H-tetrazolium) (MTT), Direct Red 80, and ethylene diamine tetra acetic acid (EDTA) were purchased from Sigma, USA. All the other chemicals used in this experiment were analytical grade procured from India.

\subsection{Cell Culture}

The human bone osteosarcoma cells (MG-63) were used as the test system in this experiment. The MG-63 cells supplemented with $10 \%$ FBS were maintained under the DMEM growth medium for routine culture. Growth conditions were maintained as $37^{\circ} \mathrm{C}, 5 \% \mathrm{CO}_{2}$ and $95 \%$ 
humidity and subcultured by trypsinisation followed by splitting the cell suspension into fresh flasks and supplementing with fresh cell growth medium. Three days prior the start of the experiment (i.e., day -3), the growth medium of near-confluent cells was replaced with fresh phenol-free DMEM, supplemented with $10 \%$ charcoal dextran stripped FBS (CD-FBS) and 1\% penicillinstreptomycin [38].

\subsection{Experimental Design}

The experimental groups consisted of cells in baseline control, vehicle control groups $(0.05 \%$ DMSO with Biofield Energy Treated and untreated DMEM), a positive control group (rutin hydrate) and experimental test groups. The experimental groups included the combination of the Biofield Energy Treated and untreated vitamin $\mathrm{D}_{3} / \mathrm{DMEM}$. It consisted of four major treatment groups on specified cells with UT-DMEM + UT-Test item, UT-DMEM + Biofield Energy Treated test item (BT-Test item), BT-DMEM + UTTest item, and BT-DMEM + BT-Test item.

\subsection{Consciousness Energy Healing Treatment Strategies}

The test item (vitamin $\mathrm{D}_{3}$ ) and DMEM were divided into two parts. One part each of the test item and DMEM were treated with the Biofield Energy (also known as The Trivedi Effect ${ }^{\circledR}$ ) and coded as the Biofield Energy Treated items, while the second part did not receive any sort of treatment and was defined as the untreated samples. This Biofield Energy Healing Treatment was provided by Brian Anthony Weekes, who participated in this study and performed the Biofield Energy Healing Treatment remotely for $\sim 5$ minutes. Biofield Energy Healer was remotely located in the USA, while the test samples were located in the research laboratory of Dabur Research Foundation, New Delhi, India. The Biofield Energy Treatment was administered for 5 minutes through the healer's unique Energy Transmission process remotely to the test samples under laboratory conditions. Brian Anthony Weekes in this study, never visited the laboratory in person, nor had any contact with the test item and medium. Further, the control group was treated with a sham healer for comparative purposes. The sham healer did not have any knowledge about the Biofield Energy Treatment. After that, the Biofield Energy Treated and untreated samples were kept in similar sealed conditions for experimental study.

\subsection{Determination of Non-Cytotoxic Concentration}

The cell viability test was performed by MTT assay in the human bone osteosarcoma cell line (MG-63). The cells were counted and plated in 96 well plates at the density corresponding to $5 \times 10^{3}$ to $10 \times 10^{3}$ cells/well $/ 180 \mu \mathrm{L}$ of cell growth medium. The above cells were incubated overnight under growth conditions and allowed cell recovery and exponential growth, then they were subjected to serum stripping or starvation. The cells were treated with the test item, DMEM, and the positive control. The untreated cells served as baseline control. The cells in the above plate (s) were incubated for a time point ranging from 24 to 72 hours in $\mathrm{CO}_{2}$ incubator at $37^{\circ} \mathrm{C}, 5 \% \mathrm{CO}_{2}$ and $95 \%$ humidity. Following incubation, the plates were taken out and $20 \mu \mathrm{L}$ of $5 \mathrm{mg} / \mathrm{mL}$ of MTT solution was added to all the wells followed by an additional incubation for 3 hours at $37^{\circ} \mathrm{C}$. The supernatant was aspirated and $150 \mu \mathrm{L}$ of DMSO and was added to each well to dissolve formazan crystals. The absorbance of each well was read at $540 \mathrm{~nm}$ using a Synergy HT micro plate reader, BioTek, USA. The percentage cytotoxicity at each tested concentration of the test substance was calculated using the following Equation 1:

$$
\% \text { Cytotoxicity }=\{(1-\mathrm{X}) / \mathrm{R}\} * 100
$$

Where, $\mathrm{X}=$ Absorbance of treated cells; $\mathrm{R}=$ Absorbance of untreated cells

The percentage cell viability corresponding to each treatment was then be obtained using the following Equation 2:

$$
\% \text { Cell Viability }=100-\% \text { Cytotoxicity }
$$

The concentrations exhibiting $\geq 70 \%$ Cell viability was considered as non-cytotoxic [39].

\subsection{Assessment of Alkaline Phosphatase (ALP) Activity}

The cells were counted using an hemocytometer and plated in a 24-well plate at the density corresponding to $1 \times 10^{4}$ cells/well in phenol free DMEM supplemented with $10 \%$ CD-FBS. Following the respective treatments, the cells in the above plate were incubated for 48 hours in $\mathrm{CO}_{2}$ incubator at $37^{\circ} \mathrm{C}, 5 \% \quad \mathrm{CO}_{2}$ and $95 \%$ humidity. After 48 hours of incubation, the plate was taken out and processed for the measurement of ALP enzyme activity. The cells were washed with 1X PBS and lysed by freeze thaw method i.e., incubation at $-80^{\circ} \mathrm{C}$ for 20 minutes followed by incubation at $37^{\circ} \mathrm{C}$ for 10 minutes. To the lysed cells, $50 \mu \mathrm{L}$ of substrate solution i.e., $5 \mathrm{mM}$ of $p$-nitrophenyl phosphate ( $p$ NPP) in $1 \mathrm{M}$ diethanolamine and $0.24 \mathrm{mM}$ magnesium chloride $\left(\mathrm{MgCl}_{2}\right)$ solution ( $\mathrm{pH}$ 10.4) was added to all the wells followed by incubation for 1 hour at $37^{\circ} \mathrm{C}$. The absorbance of the above solution was read at $405 \mathrm{~nm}$ using Synergy HT micro plate reader (Biotek, USA). The absorbance values obtained were normalized with substrate blank ( $p$ NPP solution alone) absorbance values. The percentage increase in ALP enzyme activity with respect to the untreated cells (baseline group) was calculated using Equation 3:

$$
\% \text { Increase in ALP }=\{(\mathrm{X}-\mathrm{R}) / \mathrm{R}\} * 100
$$

Where, $\mathrm{X}=$ Absorbance of cells corresponding to positive control and test groups

$\mathrm{R}=$ Absorbance of cells corresponding to baseline group (untreated cells)

\subsection{Assessment of Collagen Synthesis}

The MG-63 cells were counted using an hemocytometer and plated in 24-well plate at the density corresponding to 10 
x $10^{3}$ cells/well in phenol free DMEM supplemented with $10 \% \mathrm{CD}-\mathrm{FBS}$. Following the respective treatments, the cells in the above plate were incubated for 48 hours in $\mathrm{CO}_{2}$ incubator at $37^{\circ} \mathrm{C}, 5 \% \mathrm{CO}_{2}$ and $95 \%$ humidity. After 48 hours of incubation, the plate was taken out and the amount of collagen accumulated in MG-63 cells corresponding to each treatment was measured by Direct Sirius red dye binding assay. In brief, the cell layers were washed with PBS and fixed in Bouin's solution (5\% acetic acid, 9\% formaldehyde and $0.9 \%$ picric acid) for 1 hour at room temperature (RT). After 1 hour of incubation, the above wells were washed with milliQ water and air dried. The cells were then stained with Sirius red dye solution for 1 hour at RT followed by washing in $0.01 \mathrm{~N} \mathrm{HCl}$ to remove unbound dye. The collagen dye complex obtained in the above step was dissolved in $0.1 \mathrm{~N} \mathrm{NaOH}$ and absorbance was read at $540 \mathrm{~nm}$ using Biotek Synergy HT micro plate reader. The level of collagen was extrapolated using standard curve obtained from purified Calf Collagen Bornstein and Traub Type I (Sigma Type III). The percentage increase in collagen level with respect to the untreated cells (baseline group) was calculated using Equation 4:

$$
\% \text { Increase in collagen levels }=\{(\mathrm{X}-\mathrm{R}) / \mathrm{R}\} * 100
$$

Where, $\mathrm{X}=$ Collagen levels in cells corresponding to positive control and test groups

$\mathrm{R}=$ Collagen levels in cells corresponding to baseline group (untreated cells)

\subsection{Assessment of Bone Mineralization by Alizarin Red S Staining}

The MG-63 cells were counted using an hemocytometer and plated in 24-well plate at the density corresponding to 10 $\mathrm{x} 10^{3}$ cells/well in phenol free DMEM supplemented with $10 \% \mathrm{CD}-\mathrm{FBS}$. Following the respective treatments, the cells in the above plate were incubated for 48 hours in $\mathrm{CO}_{2}$ incubator at $37^{\circ} \mathrm{C}, 5 \% \mathrm{CO}_{2}$ and $95 \%$ humidity to allow cell recovery and exponential growth. Following overnight incubation, the above cells were subjected to serum stripping for 24 hours. The cells were then treated with non-cytotoxic concentrations of the test samples and positive control. Following 3-7 days of incubation with the test samples and positive control, the plates were taken out, cell layers processed further by staining with Alizarin Red S dye. The cells were fixed in $70 \%$ ethanol for 1 hour, after which Alizarin Red solution ( $40 \mu \mathrm{m} ; \mathrm{pH} 4.2)$ was added to the samples for 20 minutes with shaking. The cells were washed with distilled water to remove unbound dye. For quantitative analysis by absorbance evaluation, nodules were solubilized with $10 \%$ cetylpyridinium chloride for 15 minutes with shaking. Absorbance was measured at $562 \mathrm{~nm}$ using Biotek Synergy HT micro plate reader. The percentage increase in bone mineralization with respect to the untreated cells (baseline group) was calculated using the following Equation 5:

$$
\% \text { Increase }=\{(\mathrm{X}-\mathrm{R}) / \mathrm{R}\} * 100
$$

Where, $\mathrm{X}=$ Absorbance in cells corresponding to positive control or test groups; $\mathrm{R}=$ Absorbance in cells corresponding to baseline (untreated) group.

\subsection{Statistical Analysis}

All the values were represented as percentage of the respective parameters. For statistical analysis Sigma-Plot (version 11.0) was used as a statistical tool. Statistically significant values were set at the level of $p \leq 0.05$.

\section{Results and Discussion}

\subsection{MTT Assay}

The percentage of viable cells after treatment with the Consciousness Energy Healing based vitamin $\mathrm{D}_{3}$ and DMEM by MTT assay in MG-63 cells are shown in Figure 1. The percentage of cell viability was found in the ranges of $73 \%$ to $138 \%$ in the tested concentrations of all the groups and did not exhibit any cytotoxicity (as evidence of cell viability approximately greater than 73\%) across all the tested concentrations upto $100 \mu \mathrm{g} / \mathrm{mL}$. Therefore, the safe concentrations were used in this experiment to see the effect of the test samples on the levels of alkaline phosphatase (ALP) activity, collagen synthesis, and bone mineralization in MG-63 cells.

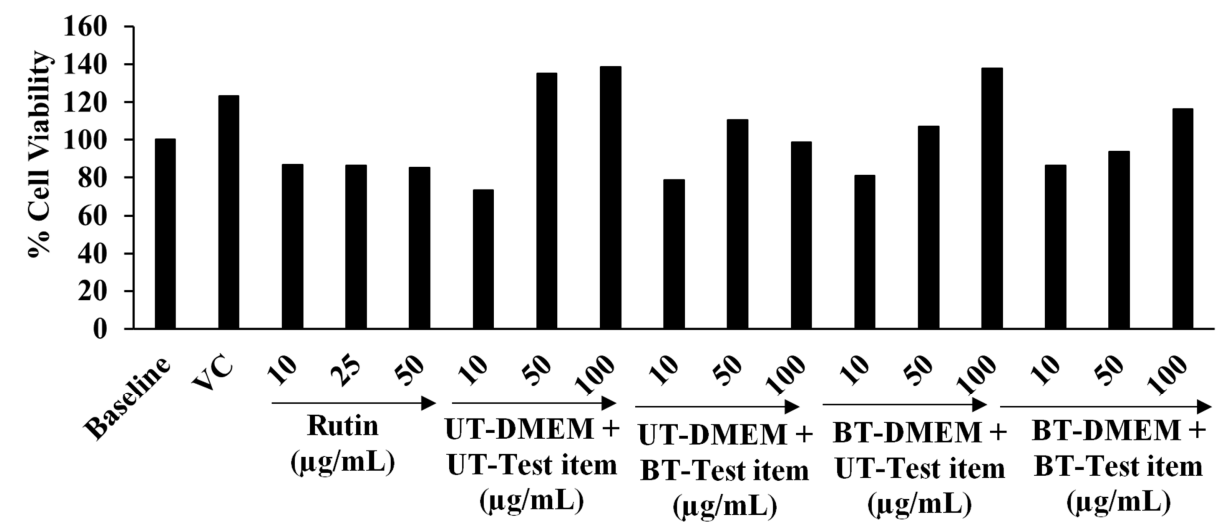

Figure 1. Evaluation of cell viability of the test items (vitamin $D_{3}$ and DMEM medium) after Biofield Energy Treatment in different tested concentrations in MG-63 cells. VC: Vehicle control (0.05\% DMSO); UT: Untreated; BT: Biofield Energy Treated. 


\subsection{Alkaline Phosphatase (ALP) Assay}

Alkaline phosphatase (ALP) is one of the biomarker for the assessment of bone formation and resorption [40,6]. This enzyme can be available in the serum either from liver or bone [41]. Numerous studies reported that besides ALP, calcium, vitamin $\mathrm{D}$, and anaerobic exercise also equal role for the development and remodeling of bone [42]. The effect of the Biofield Energy Treated test items on ALP in human bone osteosarcoma cells is shown in Figure 2. The level of ALP was found as $12.8 \%$ in the vehicle control (VC) group compared to the untreated cells group. The ALP activity was significantly increased by $33.97 \%, 45.69 \%$, and $79.66 \%$ in the positive control group at the concentration of $0.01,0.1$, and $1 \mu \mathrm{g} / \mathrm{mL}$, respectively compared to the untreated cells group. The level of ALP was increased by $19.49 \%$ and $63.49 \%$ in the UT-DMEM + BT-Test item and BT-DMEM +
BT-Test item group, at the concentration of $1 \mu \mathrm{g} / \mathrm{mL}$ compared to the UT-DMEM + UT-Test item group. Further, the level of ALP was significantly increased by $35.92 \%$ and $61.17 \%$ in the UT-DMEM + BT-Test item and BT-DMEM + BT-Test item groups, respectively at $10 \mu \mathrm{g} / \mathrm{mL}$ compared to the UT-DMEM + UT-Test item group. Further, the ALP level was significantly elevated by $42.09 \%, 27.74 \%$, and $10.40 \%$ in the UT-DMEM + BT-Test item, BT-DMEM + UT-Test item, and BT-DMEM + BT-Test item groups, respectively at $50 \mu \mathrm{g} / \mathrm{mL}$ compared to the UT-DMEM + UT-Test item group. Overall, the Consciousness Energy Healing Treated (The Trivedi Effect ${ }^{\mathbb{B}}$ ) test item group (i.e., vitamin $\mathrm{D}_{3}$ ) showed an improved synthesis of ALP level in the human osteosarcoma cells with respect to the untreated item items group, which might be very helpful to the patients suffering from various bone-related disorders.

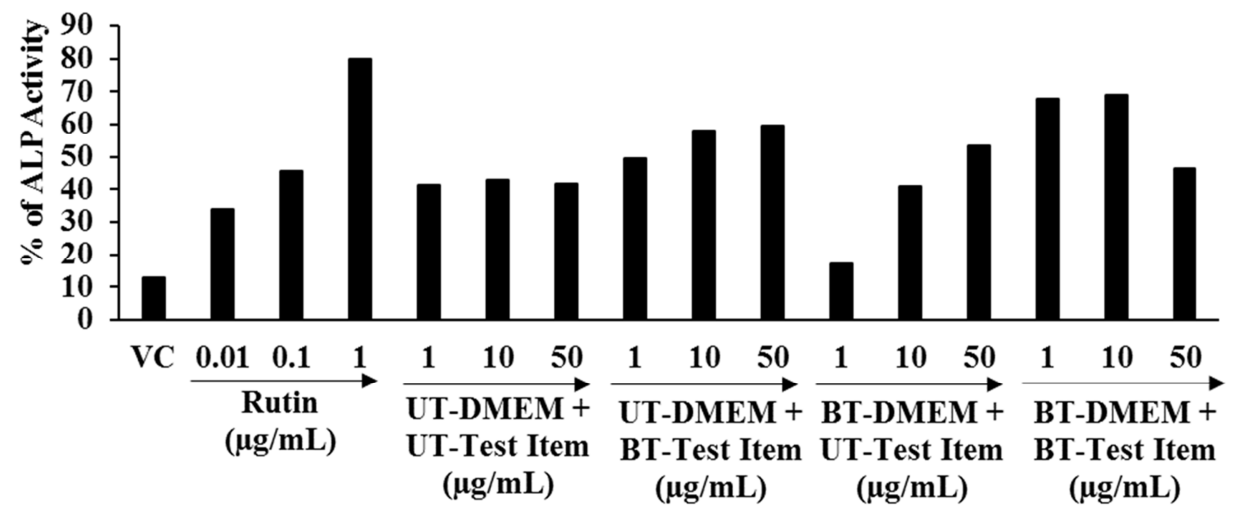

Figure 2. The effect of the test items on alkaline phosphatase (ALP) enzyme activity in human bone osteosarcoma cell. VC: Vehicle control (0.05\% DMSO), UT: Untreated; BT: Biofield Energy Treated.

\subsection{Assessment of Collagen Activity}

The effect of the test items on collagen activity in human bone osteosarcoma cells is shown in Figure 3. Collagen level in the VC group was found as $19.4 \%$ increased as compared to the untreated cells group. The positive control (rutin hydrate) exhibited $25.81 \%, 51.61 \%$, and $51.91 \%$ level of collagen content at $0.01,0.1$, and $1 \mu \mathrm{g} / \mathrm{mL}$, respectively compared to the untreated cells group. The collagen synthesis was significantly increased by $53.75 \%$ and $42.43 \%$ in the UT-DMEM + BT-Test item and BT-DMEM + UT-Test item groups, respectively at $1 \mu \mathrm{g} / \mathrm{mL}$ compared to the UT-DMEM + UT-Test item group. Moreover, the collagen level was significantly increased by $25.87 \%$ and $37.92 \%$ in the UTDMEM + BT-Test item and BT-DMEM + UT-Test item groups, respectively at $10 \mu \mathrm{g} / \mathrm{mL}$ compared to the UTDMEM + UT-Test item group. Additionally, at $50 \mu \mathrm{g} / \mathrm{mL}$ the level of collagen was also significantly increased by $46.54 \%$ and $11.45 \%$ in the BT-DMEM + UT-Test item and BTDMEM + BT-Test item groups, respectively with respect to the UT-DMEM + UT-Test item group. Further, collagen content was significantly increased by $122.61 \%$ and $6.57 \%$ in the BT-DMEM + UT-Test item and BT-DMEM + BT-Test item groups respectively, at $100 \mu \mathrm{g} / \mathrm{mL}$ with respect to the UT-DMEM + UT-Test item group (Figure 3). Altogether, the
Consciousness Energy Healing based test item group (i.e., vitamin $\mathrm{D}_{3}$ ) showed an improved synthesis of collagen content in the human osteosarcoma cells with respect to all the treatment groups.

Type 1 collagen is the most abundant in all the connective tissue. According to Takeda et al., type I collagen represents $25 \%$ of the total body protein and $80 \%$ of connective tissue in humans. The synthesis of type I collagen plays an vital role in osteoblast differentiation, enhancing bone mineral density, bone mineral content and increasing the amount of type I collagen in the bone matrix [43]. Collagen is comprised of about $25 \%$ to $35 \%$ of the total body proteins, mainly distributed in the extracellular matrix compartment. Some factors such as aging and a poor diet can affect the level of collagen in the body [44]. Because, in aged peoples the intake of food nutrition are not adequate as per recommended in terms of energy. Hence, in the senile stage of peoples are more chances to develop a bone or jointrelated disorders. For that a balance nutrition including vitamin D3 is very essential to fight against bone-related disorders and to maintain a healthy body that ensure the proper functioning $[45,46]$. It is well established that collagen is responsible for maintaining the structural integrity of various organs such as skin, tendons, ligaments, cartilages 
etc. in the vertebrates and multicellular organisms [10]. A numerous literatures reported that supplementation of collagen peptides enhanced skin elasticity, bone density, and reduced the severity of bone-related disorders [47]. In this experiment, the Biofield Energy Treated vitamin $\mathrm{D}_{3}$ significantly improved the level of collagen which might be helpful to maintain a healthy bone in postmenopausal women selectively. Overall, The Trivedi Effect ${ }^{\circledR}$ - Consciousness Energy Healing Treatment modality showed a significant improvement of the collagen level in human osteosarcoma cells. Thus, it is assumed that The Trivedi effect ${ }^{\circledR}$ has the significant potential to improve the bone health in various skeletal disorders.

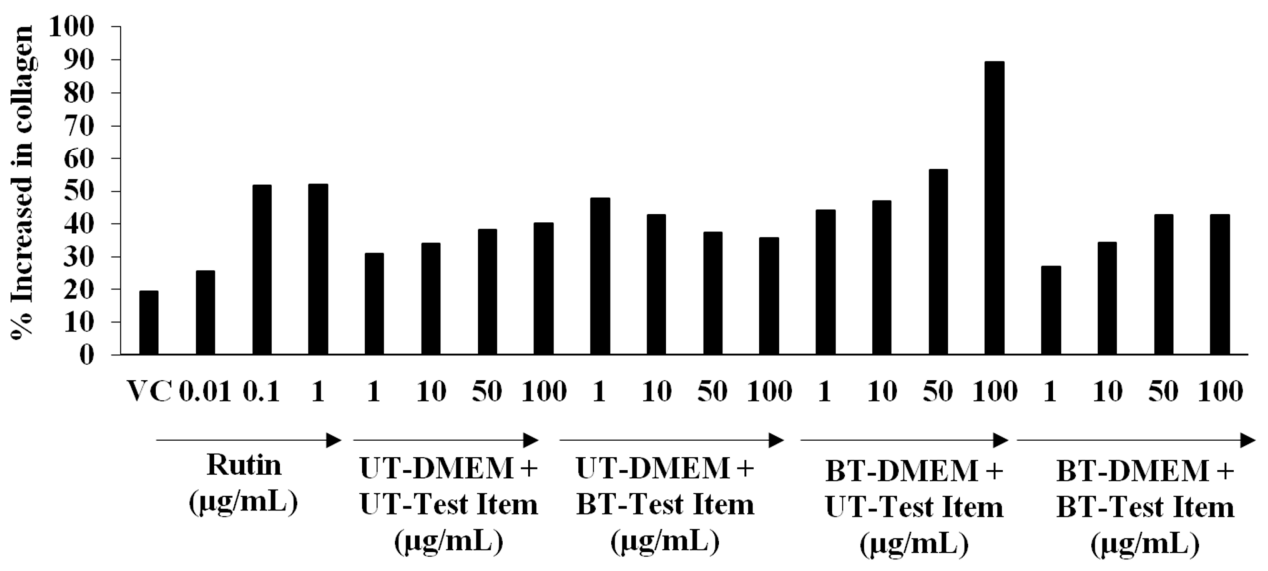

Figure 3. The effect of the test samples on collagen in human bone osteosarcoma cells. VC: Vehicle control (0.05\% DMSO), UT: Untreated; BT: Biofield Energy Treated.

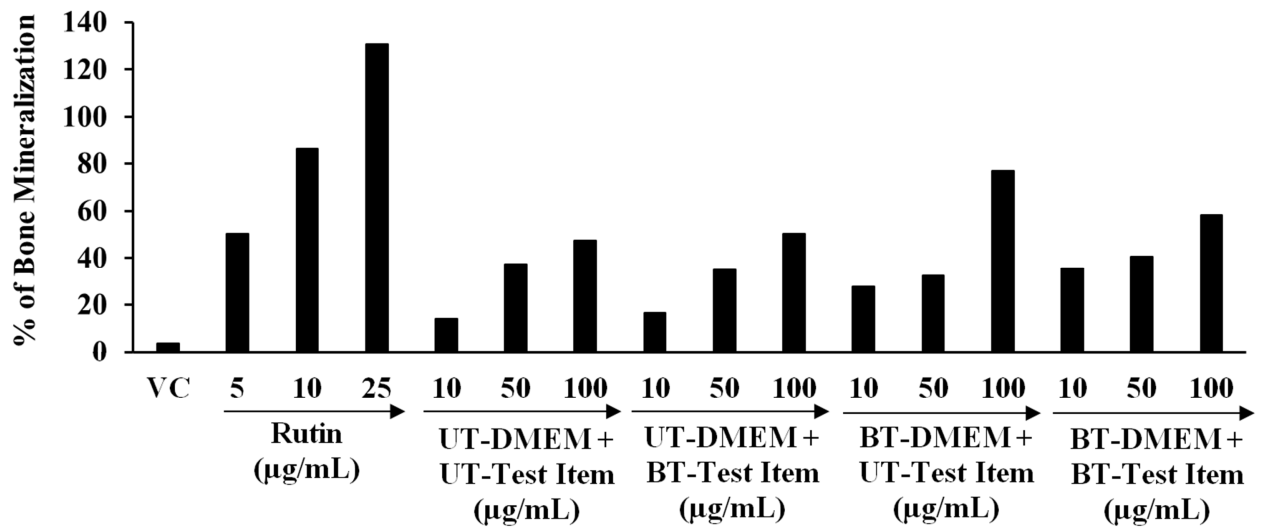

Figure 4. The effect of the test samples on bone mineralization in human bone osteosarcoma cells. VC: Vehicle control (0.05\% DMSO), UT: Untreated; BT: Biofield Energy Treated.

\subsection{Bone Mineralization}

The effect of Biofield Energy Treatment on bone mineralization in human bone osteosarcoma cells is shown in Figure 4. The percentage of bone mineralization was significantly increased in a concentration dependent manner by $50.46 \%, 86.16 \%$, and $130.60 \%$ at 5,10 , and $25 \mu \mathrm{g} / \mathrm{mL}$, respectively in the positive control group compared to the untreated cells group. The percent of bone mineralization was distinctly increased by $18.12 \%, 96.33 \%$, and $150.85 \%$ in the UT-DMEM + BT-Test item, BT-DMEM + UT-Test item, and BT-DMEM + BT-Test item groups, respectively at 10 $\mu \mathrm{g} / \mathrm{mL}$ compared to the UT-DMEM + UT-Test item group. Further, an increased percentage of bone mineralization was observed by $8.27 \%$ in the BT-DMEM + BT-Test item group at $50 \mu \mathrm{g} / \mathrm{mL}$ with respect to the UT-DMEM + UT-Test item group. Moreover, the percentage of bone mineralization was significantly increased by $5.99 \%, 61.96$, and $22.84 \%$ in the
UT-DMEM + BT-Test item, BT-DMEM + UT-Test item, and BT-DMEM + BT-Test item groups, respectively at 100 $\mu \mathrm{g} / \mathrm{mL}$ compared to the UT-DMEM + UT-Test item group (Figure 4). Vitamin D has a well-recognized role in bone biology, it is essentially required for normal bone formation and normal mineralization. Numerous observations in humans have clearly demonstrated that vitamin D is essential to prevent rickets in growing animals [48]. Deficiency of calcium and vitamin-D is a major risk factor for osteoporosis. Most of postmenopausal women are high risk for developing this disease due to aging, genetic, environmental, hormonal, nutritional, and life style factors [49]. To overcome these factors some medications are available such as direct supplementation with estrogen, calcitonin, bisphosphonate, calcium, and vitamin $\mathrm{D}_{3}$ [50]. Thus, in this experiment, authors have found that the Biofield Energy Treated vitamin $\mathrm{D}_{3}$ significantly enhanced the level of bone mineralization in the form of calcium, assessed by Alizarin Red S Staining 
technique. Therefore, based on the above findings it is hypothesized that the Consciousness Energy Healing Treatment (The Trivedi Effect ${ }^{\circledR}$ ) based test item groups (i.e., vitamin $\mathrm{D}_{3}$ ) showed a remarkable improvement of bone mineralization content assessed by in vitro in the human osteosarcoma cells (MG-63).

\section{Conclusions}

The results of cell viability using MTT assay showed more than $73 \%$ cells were viable, which indicated that the test samples were safe and nontoxic in all the tested concentrations. The level of ALP was significantly increased by $63.49 \%$ and $61.17 \%$ in the BT-DMEM + BT-Test item group at 1 and $10 \mu \mathrm{g} / \mathrm{mL}$, respectively compared to the UTDMEM + UT-Test item group. Collagen was significantly increased by $53.75 \%$ and $42.43 \%$ in the UT-DMEM + BTTest item and BT-DMEM + UT-Test item group, respectively at $1 \mu \mathrm{g} / \mathrm{mL}$ compared to the untreated group. Further, the collagen level was significantly increased by $46.54 \%$ and $122.61 \%$ at 50 and $100 \mu \mathrm{g} / \mathrm{mL}$, respectively in the BTDMEM + UT-Test item group compared to the untreated group. Further, the percent of bone mineralization was distinctly increased by $18.12 \%, 96.33 \%$, and $150.85 \%$ in the UT-DMEM + BT-Test item, BT-DMEM + UT-Test item, and BT-DMEM + BT-Test item groups, respectively at $10 \mu \mathrm{g} / \mathrm{mL}$ compared to the untreated group. Further, the percentage of bone mineralization was significantly increased by 61.96 and $22.84 \%$ in the BT-DMEM + UT-Test item and BT-DMEM + BT-Test item groups, respectively at $100 \mu \mathrm{g} / \mathrm{mL}$ compared to the UT-DMEM + UT-Test item group. Altogether, the Biofield Energy Treated test samples (The Trivedi Effect ${ }^{\circledR}$ ) demonstrated a significant impact on bone health parameters. Therefore, the Consciousness Energy Healing based vitamin $\mathrm{D}_{3}$ might be suitable for the development of an alternative and more effective supplement for vitamin $\mathrm{D}_{3}$ deficiency, which could be useful for the management of various bone related disorders viz. Paget's disease of bone, low bone density and osteoporosis, osteogenesis imperfecta, rickets, deformed bones, osteomalacia, osteoma, bone and joint pain, bone fractures, chondrodystrophia fetalis, etc. Besides, it can also be utilized in organ transplants (for example kidney transplants, liver transplants and heart transplants), various autoimmune disorders such as Lupus, Addison Disease, Celiac Disease (gluten-sensitive enteropathy), Dermatomyositis, Graves' Disease, Hashimoto Thyroiditis, Rheumatoid Arthritis, Multiple Sclerosis, Myasthenia Gravis, Pernicious Anemia, Scleroderma, Aplastic Anemia, Reactive Arthritis, Fibromyalgia, Sjogren Syndrome, Systemic Lupus Erythematosus, Vitiligo, Type 1 Diabetes, Alopecia Areata, Crohn's Disease, Psoriasis, Chronic Fatigue Syndrome and Vasculitis, as well as inflammatory disorders such as Asthma, Ulcerative Colitis, Irritable Bowel Syndrome, Atherosclerosis, Alzheimer's Disease, Dermatitis, Diverticulitis, Hepatitis, inflammatory diseases, antiinflammatory, anti-arthritic, anti-osteoporosis, anti-apoptotic, anti-stress, wound healing, anti-cancer, anti-aging, anti- psychotic and anti-fibrotic action, stress management and prevention, Parkinson's Disease etc. to modulate the immune system by improving Quality of Life.

\section{Abbreviations}

MG-63: Human Bone Osteosarcoma Cells, ALP: Alkaline phosphatase, CAM: Complementary and alternative medicine, NHIS: National Health Interview Survey, NCCIH: National Center of Complementary and Integrative Health, DMEM: Dulbecco's modified eagle's medium, FBS: Fetal bovine serum, ATCC: American type culture collection, UT: Untreated, BT: Biofield Energy Treated.

\section{Acknowledgements}

Authors are grateful to Dabur Research Foundation, Trivedi Global, Inc., Trivedi Science, Trivedi Testimonials and Trivedi Master Wellness for their support throughout the work.

\section{References}

[1] Holick MF (2004) Sunlight and vitamin D for bone health and prevention of autoimmune diseases cancers, and cardiovascular disease. Am J Clin Nut 80: 1678S-1688S.

[2] Holick MF (1996) Vitamin D and bone health. J Nutr 126: 1159S-1164S.

[3] Matsuoka LY, Ide L, Wortsman J, Mac Laughlin JA, Holick MF (1987) Sunscreens suppress vitamin $\mathrm{D}_{3}$ synthesis. J Clin Endocrinol Metab 64: 1165-1168.

[4] Barnes MS, Robson JP, Bonham MP, Strain J, Wallace J (2006) Vitamin D: Status, supplementation and immunomodulation. Cur Nut Food Sci 2: 315-336.

[5] Laird E, Ward M, McSorley E, Strain JJ, Wallace J (2010) Vitamin D and bone health; Potential mechanisms. Nutrients 2: 693-724.

[6] Bhattarai T, Bhattacharya K, Chaudhuri P, Sengupta P (2014) Correlation of common biochemical markers for bone turnover, serum calcium, and alkaline phosphatase in postmenopausal women. The Malaysian Journal of Medical Sciences : MJMS 21: 58-61.

[7] Iba K, Takada J, Yamashita T (2004) The serum level of bonespecific alkaline phosphatase activity is associated with aortic calcification in osteoporosis patients. J Bone Miner Metab 22: 594-596.

[8] Holick MF, Garabedian M (2006) Vitamin D: Photobiology, metabolism, mechanism of action, and clinical applications. Primer on the metabolic bone diseases and disorders of mineral metabolism. Edited by: Favus MJ, Washington, DC.

[9] DeLuca HF (2004) Overview of general physiologic features and functions of vitamin D. Am J Clin Nutr 80: 1689S-1696S.

[10] Viguet-Carrin S, Garnero P, Delmas PD (2006) The role of collagen in bone strength. Osteoporos Int 17: 319-336. 
[11] Sroga GE, Vashishth D (2012) Effects of bone matrix proteins on fracture and fragility in osteoporosis. Curr Osteoporos Rep 10: $141-150$.

[12] Lutgendorf SK, Mullen-Houser E, Russell D, Degeest K, Jacobson G, Hart L, Bender D, Anderson B, Buekers TE, Goodheart MJ, Antoni MH, Sood AK, Lubaroff DM (2010) Preservation of immune function in cervical cancer patients during chemoradiation using a novel integrative approach. Brain Behav and Immun 24: 1231-1240.

[13] Ironson G, Field T, Scafidi F, Hashimoto M, Kumar M, Kumar A, Price A, Goncalves A, Burman I, Tetenman C, Patarca R, Fletcher MA (1996) Massage therapy is associated with enhancement of the immune system's cytotoxic capacity. Int J Neurosci 84: 205-217.

[14] Jain S, Hammerschlag R, Mills P, Cohen L, Krieger R, Vieten C, Lutgendorf S (2015) Clinical studies of biofield therapies: Summary, methodological challenges, and recommendations. Glob Adv Health Med 4: 58-66.

[15] Rubik B (2002) The biofield hypothesis: Its biophysical basis and role in medicine. J Altern Complement Med 8: 703-717.

[16] Trivedi MK, Patil S, Shettigar H, Mondal SC, Jana S (2015) The potential impact of biofield treatment on human brain tumor cells: A time-lapse video microscopy. J Integr Oncol 4: 141.

[17] Trivedi MK, Patil S, Shettigar H, Gangwar M, Jana S (2015) In vitro evaluation of biofield treatment on cancer biomarkers involved in endometrial and prostate cancer cell lines. J Cancer Sci Ther 7: 253-257.

[18] Trivedi MK, Branton A, Trivedi D, Nayak G, Mondal SC, Jana S (2015) Antibiogram, biochemical reactions and biotyping of biofield treated Providencia rettgeri. American Journal of Health Research 3: 344-351.

[19] Trivedi MK, Branton A, Trivedi D, Nayak G, Mondal SC, Jana S (2015) Antimicrobial sensitivity, biochemical characteristics and biotyping of Staphylococcus saprophyticus: An impact of biofield energy treatment. J Women's Health Care 4: 271.

[20] Trivedi MK, Branton A, Trivedi D, Nayak G, Shettigar H, Mondal SC, Jana S (2015) Antimicrobial susceptibility pattern, biochemical characteristics and biotyping of Salmonella paratyphi A: An impact of biofield treatment. Clin Microbiol 4: 215.

[21] Trivedi MK, Branton A, Trivedi D, Nayak G, Mondal SC, Jana S (2015) Antibiogram of biofield-treated Shigella boydii: Global burden of infections. Science Journal of Clinical Medicine 4: 121-126.

[22] Trivedi MK, Branton A, Trivedi D, Nayak G, Mondal SC, Jana S (2015) Evaluation of antibiogram, genotype and phylogenetic analysis of biofield treated Nocardia otitidis. Biol Syst Open Access 4: 143.

[23] Trivedi MK, Branton A, Trivedi D, Nayak G, Charan S, Jana S (2015) Phenotyping and 16S rDNA analysis after biofield treatment on Citrobacter braakii: A urinary pathogen. J Clin Med Genom 3: 129.

[24] Trivedi MK, Patil S, Shettigar H, Bairwa K, Jana S (2015) Spectroscopic characterization of chloramphenicol and tetracycline: An impact of biofield. Pharm Anal Acta 6: 395.
[25] Trivedi MK, Patil S, Shettigar H, Bairwa K, Jana S (2015) Spectroscopic characterization of biofield treated metronidazole and tinidazole. Med Chem 5: 340-344.

[26] Trivedi MK, Patil S, Shettigar H, Bairwa K, Jana S (2015) Effect of biofield treatment on spectral properties of paracetamol and piroxicam. Chem Sci J 6: 98.

[27] Trivedi MK, Branton A, Trivedi D, Shettigar H, Bairwa K, Jana S (2015) Fourier transform infrared and ultravioletvisible spectroscopic characterization of biofield treated salicylic acid and sparfloxacin. Nat Prod Chem Res 3: 186.

[28] Trivedi MK, Branton A, Trivedi D, Nayak G, Mondal SC, Jana S (2015) Morphological characterization, quality, yield and DNA fingerprinting of biofield energy treated alphonso mango (Mangifera indica L.). Journal of Food and Nutrition Sciences 3: 245-250.

[29] Trivedi MK, Branton A, Trivedi D, Nayak G, Gangwar M, Jana S (2015) Agronomic characteristics, growth analysis, and yield response of biofield treated mustard, cowpea, horse gram, and groundnuts. International Journal of Genetics and Genomics 3: 74-80.

[30] Trivedi MK, Branton A, Trivedi D, Nayak G, Gangwar M, Jana S (2015) Analysis of genetic diversity using simple sequence repeat (SSR) markers and growth regulator response in biofield treated cotton (Gossypium hirsutum L.). American Journal of Agriculture and Forestry 3: 216-221.

[31] Trivedi MK, Branton A, Trivedi D, Nayak G, Gangwar M, Jana $S$ (2015) Evaluation of vegetative growth parameters in biofield treated bottle gourd (Lagenaria siceraria) and okra (Abelmoschus esculentus), International Journal of Nutrition and Food Sciences 4: 688-694.

[32] Trivedi MK, Tallapragada RM, Branton A, Trivedi D, Nayak G, Latiyal O, Jana S (2015) Evaluation of atomic, physical, and thermal properties of bismuth oxide powder: An impact of biofield energy treatment. American Journal of Nano Research and Applications 3: 94-98.

[33] Trivedi MK, Patil S, Nayak G, Jana S, Latiyal O (2015) Influence of biofield treatment on physical, structural and spectral properties of boron nitride. J Material Sci Eng 4: 181.

[34] Trivedi MK, Nayak G, Patil S, Tallapragada RM, Latiyal O, Jana S (2015) Characterization of physical and structural properties of brass powder after biofield treatment. J Powder Metall Min 4: 134.

[35] Trivedi MK, Nayak G, Patil S, Tallapragada RM, Latiyal O, Jana S (2015) Evaluation of biofield treatment on physical and structural properties of bronze powder. Adv Automob Eng 4: 119.

[36] Trivedi MK, Nayak G, Patil S, Tallapragada RM, Jana S, Mishra RK (2015) Bio-field treatment: An effective strategy to improve the quality of beef extract and meat infusion powder. J Nutr Food Sci 5: 389.

[37] Trivedi MK, Tallapragada RM, Branton A, Trivedi D, Nayak G, Mishra RK, Jana S (2015) Biofield treatment: A potential strategy for modification of physical and thermal properties of gluten hydrolysate and ipomoea macroelements. J Nutr Food Sci 5: 414.

[38] Czekanska EM, Stoddart MJ, Richards RG, Hayes JS (2012) In search of an osteoblast cell model for in vitro research. Eur Cells Mater 24: 1-17. 
[39] Biological evaluation of medical devices - Part 5: Tests for in vitro cytotoxicity (ISO 10993-5: 2009), I. S. EN ISO, 109935: 20093.

[40] Rahnama M, Swiatkowski W, Zareba S (2002) Assessment of the alkaline (ALP) and acid phosphatase (ACP) in the blood serum of rats during experimental postmenopausal osteoporosis. 53: 283-291.

[41] Masrour Roudsari J, Mahjoub S (2012) Quantification and comparison of bone-specific alkaline phosphatase with two methods in normal and paget's specimens. Caspian J Intern Med 3: 478-483.

[42] Wilhelm M, Roskovensky G, Emery K, Manno C, Valek K, Cook C (2012) Effect of resistance exercises on function in older adults with osteoporosis or osteopenia a systematic review. Physiother Can 64: 386-394.

[43] Takeda S, Jong-Hoon P, Kawashima E, Ezawa I, Omi N (2013) Hydrolyzed collagen intake increases bone mass of growing rats trained with running exercise. J Int Soc Sports Nutr 10: 35 .

[44] Shuster S (2005) Osteoporosis, a unitary hypothesis of collagen loss in skin and bone. Med Hypotheses 65: 426-432.
[45] Franzen JM, Santos JMSR, Zancanaro V (2013) Colágeno: Uma abordagem para a estética. Rev Interdiscipl Estud Saúde 2: 49-61.

[46] Cosgrove MC, Franco OH, Granger SP, Murray PG, Mayes AE (2007) Dietary nutrient intakes and skin-aging appearance among middle-aged American women. Am J Clin Nutr 86: 1225-1231.

[47] Zhang H, Zhao Y, Li Y, Sun X, Bai X, Zhao D (2010) Effects of deer tendons collagen on osteoporosis rats induced by retinoic acid. Journal of Chinese Medicinal Materials 33: 411414 .

[48] Eisman JA, Bouillon R (2014) Vitamin D: Direct effects of vitamin D metabolites on bone: Lessons from genetically modified mice. Bonekey Rep 3: 499.

[49] Jagtap VR, Ganu JV (2012) Effect of antiresorptive therapy on urinary hydroxyproline in postmenopausal osteoporosis. Indian J Clin Biochem 27: 90-93.

[50] Kuo YJ, Tsuang FY, Sun JS, Lin CH, Chen CH, Li JY, Huang YC, Chen WY, Yeh CB, Shyu JF (2012) Calcitonin inhibits SDCP-induced osteoclast apoptosis and increases its efficacy in a rat model of osteoporosis. PLoS ONE 7: e40272. 